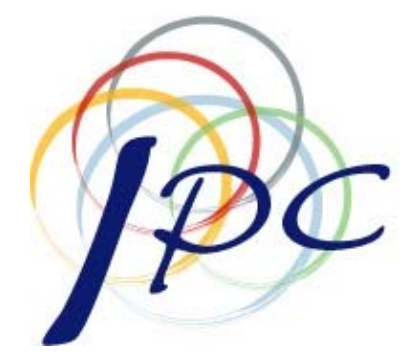

InTERnational Policy Center

Gerald R. Ford School of Public Policy University of Michigan

IPC Working Paper Series Number 8

Globalization's Bystanders:

Does Trade Liberalization Hurt Countries that Do Not Participate?

Alan V. Deardorff and Robert M. Stern

Revised November 2005 


\title{
ABSTRACT \\ Globalization’s Bystanders: \\ Does Trade Liberalization Hurt Countries that Do Not Participate?
}

\author{
Alan V. Deardorff \\ and \\ Robert M. Stern \\ Gerald R. Ford School of Public Policy and \\ Department of Economics \\ The University of Michigan
}

This paper uses trade theory to examine the effects of trade liberalization on countries that do not participate in it. These include both countries that fail to participate in multilateral trade negotiations, and also countries that lie outside of preferential trading arrangements such as free trade areas. The analysis suggests that, while it is theoretically possible for excluded countries to gain, through improved terms of trade, from trade liberalization, several reasons suggest that they are more likely to lose.

Keywords:

Globalization , Trade liberalization

JEL Subject Code:

F13 Commercial Policy

\section{Correspondence:}

Alan V. Deardorff

Gerald R. Ford School of Public Policy

University of Michigan

Ann Arbor, MI 48109-1220

Tel. 734-764-6817

Fax. 734-763-9181

E-mail: alandear@umich.edu

http://www-personal.umich.edu/ alandear/

Paper prepared for the UNU/WIDER Project Meeting on

The Impact of Globalization on the World's Poor

October 29-30, 2004, Helsinki 


\title{
Globalization's Bystanders: Does Trade liberalization Hurt Countries that Do Not Participate?
}

\author{
Alan V. Deardorff \\ and \\ Robert M. Stern \\ The University of Michigan
}

\section{Introduction}

Globalization has many meanings, and many effects. Here we will focus on only one of each: globalization as the reduction in barriers to international trade, and its effect on the countries that, for whatever reason, do not themselves participate in that process. It is often observed by proponents of globalization that, while not all countries have prospered during the recent upsurge in global integration, most of the countries that have failed to prosper, especially in Africa, have been distinctive in the extent to which they have remained relatively closed off from world markets. The supposed implications are that these countries, had they embraced trade liberalization, would have done better, and that, while trade liberalization by others has perhaps not helped these countries due to their own reluctance to participate, it has not hurt them either. They have only hurt themselves.

In this paper we use the tools of international trade theory to examine especially the second of these implications. How has trade liberalization by the larger part of the world's economy affected those countries that have not participated? Have they, perhaps,

\footnotetext{
* We have benefited from comments by participants in the UNU/WIDER meeting, and especially those from my anonymous referee, Ryes Jenkins.
} 
benefited from trade liberalization in spite of their outsider status, as free riders? Or have they instead been harmed by trade liberalization, made worse off than if trade liberalization had not occurred?

For the sake of argument, we will divide the world's countries into just two types: the "included" countries and the "excluded." The included countries are those that have substantially lowered their barriers to international trade, perhaps as part of the trade liberalization fostered by the General Agreement on Tariffs and Trade (GATT) and now the World Trade Organization (WTO), and/or perhaps through preferential trading arrangements (PTAs) such as the European Union (EU) and the North American Free Trade Agreement (NAFTA). The excluded countries are those that have stayed out of PTAs and have either failed to join the GATT/WTO or who have joined but have taken such advantage of the provision for "special and differential treatment" that their trade barriers have remained high. For the most part, these excluded countries have remained in that category through their own choice (their governments', that is) and not because the included countries would not have welcomed their participation in trade liberalization.

In principle, presumably, a country could cut itself off completely from world markets, and thus achieve an extreme form of this excluded status. From the perspective of the analysis here, such a country could not be hurt by globalization, since it would not be aware of it, except perhaps through non-economic mechanisms that we will not examine, such as trans-border pollution. Instead, the excluded countries that we will consider are engaged to some extent with world markets, exporting and importing at a moderate rate that is subject to trade barriers that are high, but that are not all prohibitive. 
It is the fact that they trade at all that makes them vulnerable to the effects of trade liberalization by others, since it may change their terms of this trade. Indeed, it is the effect of trade liberalization on an excluded country's terms of trade that will be the sole concern of this paper, and we will examine this effect through several quite standard theoretical models of international trade.

In Section II we take our first two passes at this question by using one of the oldest tools of international trade theory: the offer curve. From this we will see first how an excluded country might easily be expected to benefit, not lose, from trade liberalization by other countries. But on more careful inspection, the same tool will suggest that such a benefit is conditional on the relative extent of liberalization by two subsets of the other countries: those that export the same good as the excluded country, and those that import it. Indeed, much depends on the degree to which the included countries reduce their tariffs on the good or goods of export interest to the excluded country.

In section III, instead of simply taking as given the tariff cuts of included countries, we then ask in which sectors these tariff cuts are likely to occur. A simple "political economy" model suggests that tariffs are not likely to be cut on the products that excluded countries happen to export, thus making it more likely that they will lose from trade liberalization by other countries. This theoretical result is of course motivated by the common observation that developing countries today face higher tariffs than developed countries, a fact that, on this interpretation, can be attributed to the developing countries' own collective choice to exclude themselves from trade liberalization. 
In both of sections II and III we assume that, when included countries do lower their tariffs on particular goods, they do it on imports from all other countries, even the excluded ones. That is, this trade liberalization is done, in the WTO's language, on an MFN (most favored nation) basis. This is of course required by the WTO for imports from any countries that are themselves members of the WTO, and in fact, although it is not required, it seems to be fairly commonly done even for most excluded countries that are not members. The United States, for example, gives MFN status to almost every country in the world, even though it does not have to under WTO rules. ${ }^{1}$ The results in sections II and III, therefore, show that excluded countries may be hurt by trade liberalization of other countries, even though they remain subject to the same tariffs as everybody else.

In fact, however, they do not. Increasingly in recent years, countries who wish to participate in trade liberalization have done so not just through the MFN liberalization of the WTO, but also through PTAs negotiated among pairs or small groups of countries. In section IV, therefore, we examine the additional harm that is likely to be done to excluded countries if a significant part of trade liberalization takes this form.

In section $\mathrm{V}$ we conclude by trying to extract some policy implications from all of this. Since nothing in our analysis contradicts the traditional presumption from trade theory that trade liberalization is beneficial for the world as a whole, we certainly would not conclude that this aspect of globalization should be stopped, or even slowed down. But the harm that it may do to excluded countries needs to be recognized, and greater

\footnotetext{
${ }^{1}$ There are only two or three exceptions, including Cuba and North Korea. MFN status for China was of course a matter of annual controversy before China joined the WTO, but in practice, in spite of threats to withdraw it, China was regularly granted MFN status.
} 
efforts need to be made to deal with it. The most obvious way to do that, of course, would simply be to include them more fully in trade liberalization.

\section{When Can a Country Free Ride?}

The simplest analysis of the effect of one country's liberalization on another is provided by offer curves. Suppose there are two countries, A and E, where E will be the "excluded country" throughout the analysis in this section. Both countries produce and trade two goods, $\mathrm{X}$ and $\mathrm{Y}$. If E exports good $\mathrm{X}$, then its offer curve is something like $\mathrm{OE}$ in Figure 1 , showing the quantities of $\mathrm{X}$ that it is willing to export in exchange for various quantities imported of good Y. The slope of any line from the origin to the curve is the relative price of good $X$. The curve OE indicates that country E will import more of good $\mathrm{Y}$ only if it gets a higher relative price for its export of good $\mathrm{X}$, or equivalently, if it pays a lower relative price for its import of good Y. The curve also suggests that a higher relative price of $\mathrm{X}$ will elicit more exports from country $\mathrm{E}$, although from the curvature it is possible that beyond some point a further increase in price will cause a fall in exports. The reason is that a rise in the relative price of $\mathrm{X}$ is an improvement in country E's terms of trade, meaning that its real income rises, and it may choose to use this income to consume more of both goods, thus exporting less. In any case, it is this improvement in the terms of trade that we will be looking for, to see whether country E may benefit from liberalization elsewhere.

If $E$ were itself engaged in free trade, then we could easily use trade indifference curves $^{2}$ to indicate the level of welfare within country E, since these would be tangent to any price line from the origin where it crosses the offer curve. However, since our

\footnotetext{
${ }^{2}$ See Meade (1952).
} 
interest is in a country that certainly does not have zero tariffs, this cannot be done.

Nonetheless, because a tariff reduces a country's imports below what would be optimal, a rise in its terms of trade that permits it to import more will always improve its welfare. Therefore it will be enough, in order to infer effects on country E's welfare, to see what happens to its terms of trade.

In Figure 1, country $\mathrm{E}$ engages in trade with a single other country, $\mathrm{A}$, which is an exporter of the other good, Y. Initially country A, like E, has a tariff on its imports of good X. Then, for whatever reason (perhaps because it newly recognizes the gains from trade), it reduces that tariff. The effect, familiar from offer-curve analysis, is to shift A's offer curve outward, away from the origin, as shown, to OA'. Equilibrium moves from point 1 to point 2 in the figure, and the terms of trade of the excluded country E improve. Thus the excluded country benefits from country A's liberalization.

Of course, if the world really contained only these two countries, then one might wonder whether country A would really liberalize to this extent, since the improvement in E's terms of trade is a worsening of A's. For this reason country A, if it were sensible, might not reduce its tariff to zero, since doing so would cause it to forego some of the benefits of levying a monopoly tariff, which given country E's continuing protection there is no reason for it not to use. But if A previously had a tariff above the monopoly level, then it could gain by a tariff reduction, and country E, as shown, would gain along with it. In any case, as we now consider a world with a larger number of countries, such monopoly-tariff considerations become less relevant.

For the two-country case is hardly what we want to see. In practice, our excluded country confronts a large world of a great many countries, all of whom may be 
liberalizing. If we can think of the foreign offer curve, OA, as representing the aggregate of all those countries, then Figure 1 suggests a much more relevant gain for the excluded country $\mathrm{E}$ as a free rider on global liberalization. It must of course be true that, since $\mathrm{E}$ is an exporter of good X, the rest of the world must in aggregate be a net importer of good $\mathrm{X}$, and therefore the world's offer curve does indeed look something like OA. Since trade liberalization by any country must cause its offer curve to expand outward, Figure 1 may seem to guarantee that, in fact, excluded countries can only gain from the rest of world's liberalization.

That is not the case, however. While it is true that individual country offer curves expand with their liberalization, and it is also true that any group of countries may be represented by an aggregate offer curve that is, in effect, their sum, it is not true that liberalization by those countries necessarily expands the aggregate offer curve outward. Suppose, for example, that the rest of world consists of just two countries, one that exports $\mathrm{Y}$ and the other that imports it. If the latter imports less than the former exports, the offer curve of the two together will look like OA in Figure 1. But if now only the second of these two countries were to lower its tariff (on Y, since that is what it imports), it would import more $\mathrm{Y}$ and thus reduce, not expand, the amount that the two together export. The aggregate offer curve would shift inward.

To correctly identify the effect of liberalization on world markets, then, we need to separate countries with different trade patterns. This is done in Figure 2, where we now take the excluded country E to be very small compared to others, as suggested by drawing its offer curve, $\mathrm{OE}, 100$ times actual size. The rest of world then consists of two countries, A that exports $\mathrm{Y}$ and $\mathrm{B}$ that exports $\mathrm{X}$. In the initial equilibrium at point 1, 
world prices are determined (since country $\mathrm{E}$ is negligibly small) by the offer curves OA and OB. Now, as A and B both reduce their tariffs, both offer curves expand outward by some amounts, perhaps to $\mathrm{OA}^{\prime}$ and $\mathrm{OB}^{\prime}$, and the new equilibrium is at point 2. As drawn, the terms of trade of country E worsens. It is hurt by the rest of world's liberalization.

What determines this result? Most simply, country E (as an exporter of X) will be hurt if, at initial prices, those countries that are also net exporters of X expand their trade more than those countries that are net importers of $X$. This in turn depends, though only in part, on the sizes of the two groups of countries' tariff reductions. If the X-exporters, whose relevant tariffs are on $\mathrm{Y}$, reduce their tariffs more than the Y-exporters, whose relevant tariffs are on $\mathrm{X}$, then other things equal we may expect country $\mathrm{E}$ to lose. Conversely, in order for country E to free ride on others' liberalization, it needs greater reductions in tariffs on what it exports than on what it imports. This is not exactly right, even in this simple two-good case, since countries may differ for various reasons in the extent to which their quantities of trade respond to tariff reductions. But as a first approximation in ignorance of these other determinants of trade, what matters is these two sets of tariff reductions.

It is obvious why the excluded country gains from others' reductions in their tariffs on its exports. These cause increases in demand for its export good on world markets and thus increase its world price. But why do other countries' tariff cuts on its imports matter at all? The answer is that these tariff cuts cause world prices of the imports to rise, reducing what the excluded country can get in exchange for its exports. In a two good model, there really is no difference between a rise in export prices and fall in import prices, and the same is true with many goods if one looks at appropriate indexes 
of the prices of both. However, in the real world people seldom do look at such indexes, and the public and political perception of the effects of export prices and import prices may be quite different. We will look next at a model that allows for this.

\section{Which Tariffs Will Fall with Multilateral Liberalization?}

The point of this section is to argue what may seem obvious: that countries that do not themselves participate in tariff liberalization are likely to find that other countries do not reduce tariffs on their exports. Obvious or not, this does not follow easily from the simple welfare economics of tariffs, which says that the gain to importing countries from lowering their own tariffs does not depend on whether other countries do. Except for terms-of-trade motivations in large countries - which some though not all regard as implausible motivators for trade policies - the rest-of-world will always benefit from lowering its tariffs on a country's products, even if that country keeps its own tariffs high. Of course, the same reasoning implies that we should already see tariffs close to zero in most of the world, which we do not, and which we certainly did not see prior to the liberalizations undertaken under the GATT/WTO.

To answer this question, then, we must have some sort of model of the political economy of trade policy. Such models have been built and increasingly refined in the trade literature, with early efforts by Findlay and Wellisz (1982), Mayer (1984), and Hillman (1989), whose approaches were then integrated successfully by Grossman and Helpman (1994). For the purpose here, however, a much simpler framework will suffice, one that could perhaps be viewed as a simplification of the Grossman and Helpman model. 
The true welfare effects of a tariff reduction include the following, as a simple partial equilibrium model would suggest: a gain to domestic consumers; a loss (of tariff revenue) to the domestic government; a loss to import-competing domestic producers; and - if the size of the importing country is large enough for the tariff cut to raise the world price of the good - a gain to foreign producers and a loss to foreign consumers. In a world where the tariff was the only prior distortion, it is well known that the sum of these effects must be positive - that is, the world as a whole gains from a tariff cut. The importing country alone also gains if it is small enough that the world price is unaffected, but it may not gain if the worsening of its terms of trade outweighs the efficiency gain.

All of this may be beside the point, however, if political forces favor some constituencies over others, as seems to be the case given that virtually all countries, and especially many small ones, have had positive and often quite high tariffs throughout history. The political economy literature explains this by allowing producers to exert special influence on trade policy, by one means or another. Grossman and Helpman, in particular, model producers as contributing financially to incumbent politicians in return for their providing or maintaining tariff protection. The politicians, in turn take account of both the contributions that they receive and also broad economic welfare in making their policy decisions.

Here, however, we will assume instead that policy makers in most countries are concerned only about producer welfare, ignoring completely any gains or losses to consumers and, in most cases, ignoring also any effects of tariff revenues. This could perhaps be justified along the lines of Grossman and Helpman as an extreme case of putting all weight on the contributions that politicians receive. However it could also be 
motivated less cynically by observing that the gains and losses to producers, very much including their employees, are much easier to see than the gains and losses to consumers. Also, because they tend to be concentrated on small groups in the population, the severity of effects on producers is evident, while the effects on individual consumers may be dismissed as too small to worry about. As for also ignoring tariff revenues, that would be a dubious assumption in a country where tariffs provide the bulk of government revenues, and we will bring it back into the analysis for such countries below. But in advanced countries with many other (and more efficient) revenue generating opportunities, it seems plausible that these revenues might also play only a negligible role.

In order to incorporate this simple assumption into a correspondingly simple model, we follow Grossman and Helpman in assuming that preferences are "quasi-linear" so that, except in a numeraire sector in which we always assume free trade, demand in each country for each good depends only on its price relative to the numeraire. And we go even further than Grossman and Helpman on the production side. They assumed specific factors in each sector, with labor mobile among sectors. We assume that all factors are specific, so that output in each sector in each country is simply fixed. We also follow Grossman and Helpman in assuming that all goods are only final goods, so that there are no imported intermediate inputs. That is an important limiting assumption, as we will note.

Suppose, then, that there are $C$ countries, $c=1, \ldots, C$, and $G+1$ goods, $g=0,1, \ldots, G$, with good zero the aforementioned numeraire. All countries share the same demand functions for the non-numeraire goods, $D_{g c}=1-p_{g c}, g=1, \ldots, G$, so that trade patterns depend only on differences across countries in exogenous production levels. These take 
either of two values, a low value $\bar{X}_{g}$ in countries that will be importing the good, and a high value $\overline{\bar{X}}_{g}$ in countries that will be exporting it.

Although we will assume there is some trade, even before any liberalization, it is worth noting the autarky prices that follow from these production levels and demands: Countries with low production have a high autarky price, denoted $\widetilde{p}_{g}=1-\bar{X}_{g}$, while countries with high production have a low autarky price, $\widetilde{\widetilde{p}}_{g}=1-\overline{\bar{X}}_{g}<\widetilde{p}_{g}$. Let $\bar{S}_{g}^{C}=\left\{c \mid X_{g c}=\bar{X}_{g}\right\}$ be the set of all countries with low production of good $g$ and $\bar{N}_{g}^{C}=\left(\sum_{c \in \bar{S}_{g}^{C}} 1\right)$ be the number of those countries; define $\overline{\bar{S}}_{g}^{C}, \overline{\bar{N}}_{g}^{C}$ analogously. And let $\bar{S}_{c}^{G}=\left\{g \mid X_{g c}=\bar{X}_{g}\right\}$ be the set of all goods that country $c$ produces in small quantity; $\bar{N}_{c}^{G}$ the number of those goods; and $\overline{\bar{S}}_{c}^{G}, \overline{\bar{N}}_{C}^{G}$ analogously.

Initially, we let all countries have the same ad valorem tariff on a good, $t_{g}^{0}$, which is assumed small enough to permit trade: $t_{g}^{0}<\left(\widetilde{p}_{g}-\widetilde{\widetilde{p}}_{g}\right) / \widetilde{\widetilde{p}}_{g}$. In the initial equilibrium denoted " 0 ", exporters receive a world price $p_{g}^{W 0}$ while importers pay a higher importer's price, $p_{g}^{M 0}=\left(1+t_{g}^{0}\right) p_{g}^{W 0}$, both of which are determined by the requirement that demands, at these prices, add up to production:

$$
\overline{\bar{N}}_{g}^{C}\left(1-p_{g}^{W 0}\right)+\bar{N}_{g}^{C}\left(1-\left(1+t_{g}^{0}\right) p_{g}^{W 0}\right)=\overline{\bar{N}}_{g}^{C} \overline{\bar{X}}_{g}+\bar{N}_{g}^{C} \bar{X}_{g}
$$

from which

$$
p_{g}^{W 0}=\frac{\overline{\bar{N}}_{g}^{C} \widetilde{\widetilde{p}}_{g}+\bar{N}_{g}^{C} \widetilde{p}_{g}}{C+t_{g}^{0} \bar{N}_{g}^{C}}
$$


Now consider the possibility of all countries moving to free trade, denoted "F", in all sectors. The world price - given by (2) but with $t_{g}^{0}$ replaced by zero - is then simply the average of the two autarky prices with weights equal to the fraction of countries with each. Relevant to the choice of whether to make this change is the change in producer welfare, which since production is fixed is simply

$$
\Delta \pi_{g c}^{F}=\left(p_{g}^{W F}-p_{g c}^{0}\right) X_{g c}
$$

where $p_{g c}^{0}$ and $X_{g c}$ are to be replaced by $p_{g}^{W 0}$ and $\overline{\bar{X}}_{g}$ for an exporter and by $p_{g}^{M 0}$ and $\bar{X}_{g}$ for an importer. Letting

$$
\delta_{g c}= \begin{cases}1 & \text { if } c \in \bar{S}_{g}^{C} \\ 0 & \text { if } c \in \overline{\bar{S}}_{g}^{C}\end{cases}
$$

indicate that country $c$ imports good $g$, it turns out that

$$
\Delta \pi_{g c}^{F}=\frac{p_{g}^{W F} X_{g c}^{0} t_{g}^{0}}{C+t_{g}^{0} \bar{N}_{g}^{C}}\left(\bar{N}_{g}^{C}-\delta_{g c} C\right)
$$

Thus, as one would expect, looking only at producers' welfare, the move to free trade in one sector causes exporters to gain and importers to lose. ${ }^{3}$ It is easily confirmed, however, that the sum of these changes across all countries is positive, simply because individual exporters produce more than individual import-competitors. Summing (5) across all countries yields:

$$
\sum_{c} \Delta \pi_{g c}^{F}=\frac{p_{g}^{W F} t_{g}^{0} \bar{N}_{g}^{C} \overline{\bar{N}}_{g}^{C}}{C+t_{g}^{0} \bar{N}_{g}^{C}}\left(\overline{\bar{X}}_{g}-\bar{X}_{g}\right)>0
$$

\footnotetext{
${ }^{3}$ If we allowed for traded intermediate inputs, it would not be this simple. A local producer could benefit from a tariff cut on its input.
} 
Thus even from the perspective of producers alone, the world as a whole benefits from a move to free trade.

Individual countries may not gain in this sense, however. Certainly they lose in particular sectors if they are importers and a positive tariff is reduced, since that hurts their competing producers. And while it is true that if positive tariffs are reduced in all sectors, then they are likely to have export-sector producers who gain at the same time that import-competing producers lose, there is no guarantee that the gain to the former is larger, for a given country, than the loss to the latter. In an extreme case, a country could be an importer of every good other than the numeraire, in which case it would have no producers who gain. And even if we require a plausible mix of export and import sectors outside the numeraire, if a country happens to export only in sectors with a large number of other exporting countries, then its exporters will gain little from the liberalization. Thus there may well be countries that stand to lose, from this producers-only perspective, from a multilateral move to free trade. Such countries would presumably not participate in such a move. ${ }^{4}$

Thus an actual liberalization, if it occurs in this framework, is likely to include only a subset of the world's countries: a group of countries for whom $\mathrm{MFN}^{5}$ tariff reductions benefit their export-sector producers more than they harm their importcompeting producers. Of course, by not including tariff reductions by countries outside that group, the gains to the former are likely to be smaller than if all countries had moved

\footnotetext{
${ }^{4}$ In addition, the assumption here that governments care only about producers, and not even about their own revenues, is particularly questionable in poor countries where tariff revenues may bulk large in government budgets. Such countries, even if their export-sector producers would gain more from liberalization than their import-competitors would lose, might opt out of liberalization for that reason.

${ }^{5} \mathrm{We}$ will look are preferential agreements in the next section.
} 
together to free trade. But this may be offset by the included group simply not reducing tariffs on products that its members do not export.

Note that in this framework, a country would never unilaterally reduce its tariffs. ${ }^{6}$ To do so would provide no benefit at all to its exporters, and only harm its import competitors. So for MFN liberalization to occur, countries must find others who are willing to reduce their tariffs as well, so as to create benefits for their exporters. Whether such willing participants can be found is uncertain. It depends on the patterns of comparative advantage across countries.

Suppose, to take a simple example where limited liberalization can succeed, that there are two or more goods that importing countries do not produce at all. Then a group of countries who export different ones of these goods will necessarily benefit, as producers, if they agree to reduce tariffs on these goods alone, since the export-sector producers in each will gain from the others' tariff reductions, and they will not have any import-competing producers who will lose. Thus we know that there may exist a group of countries that will willingly reduce their tariffs on a set of goods. On the other hand, suppose that all countries but one are importers of all goods except the numeraire, on which by assumption all have zero tariffs. Then there will not exist any group of countries willing to reduce tariffs at all.

The important point, however, is the following. Suppose that there does exist a set of countries, $S^{C}$, that are willing to reduce tariffs on a set of goods, $S^{G}$. And suppose that any good within $S^{G}$ is exported only by countries not in $S^{C}$. Then producers in the countries of $S^{C}$ will gain at least as much by excluding that good from $S^{G}$ as by including

\footnotetext{
${ }^{6}$ Again, this need not be the case if there are traded intermediate inputs. Indeed any input that is only imported and not produced domestically would be eliminated based on the interests of producers that use it.
} 
it, and they will gain strictly more if any of them produce this good. Thus in this model we should not expect multilateral liberalization by a subset of the world's countries, if it occurs, to include goods that are exported only by countries outside that group. Again, of course, this would not be the case if consumer welfare were taken fully into account. ${ }^{7}$

If the outside countries export goods that are also exported by some of the inside countries, then producers in the latter would lose if these goods were removed from $S^{G}$. Their governments might still accept this exclusion, however, if they have other export producers who gain sufficiently.

The conclusion from this section, then, is that excluded countries are not likely to benefit from MFN liberalization by other countries, simply because these other countries are not likely to reduce tariffs on the goods of greatest export interest to the excluded countries. Somewhat ironically, this would not be the case if a particular excluded country were very similar, in its pattern of trade, to the countries that are liberalizing. But it is certain to be true if the excluded countries are distinctly different from the included ones, as perhaps by being less economically developed.

\section{Preferential Trade liberalization}

So far we have considered only MFN liberalization. But an increasing amount of trade liberalization in recent years has taken the form of PTAs. In these arrangements, as required by the WTO, the liberalization is typically more extreme, with tariffs reduced further and on more goods than may be covered in a multilateral WTO agreement. They are, however, discriminatory. Countries that are not part of a particular PTA continue to

\footnotetext{
${ }^{7}$ On the other hand, allowing the government to care about tariff revenues would only make the point stronger.
} 
be subject to what are still called the MFN tariffs of the PTA countries, although the MFN name is now insidiously misleading. Countries outside a PTA are not being treated as well as the "most favored nation" at all, but instead have their exports to countries within the PTA taxed at a higher rate.

The literature on PTAs, starting with Viner's (1950) analysis of customs unions and continuing today, emphasizes the positive and negative effects that arise from "trade creation" and "trade diversion." This seems to suggest that if the former somehow outweighs the latter, then the PTA is beneficial. That may be true for the countries inside the PTA, and perhaps even for the world as a whole. But it is very unlikely to be true for the countries that remain outside the PTA. For them trade creation is largely irrelevant, while trade diversion represents a loss. That is, when a PTA causes a member country to import from a partner rather than from an outside country, that constitutes a fall in demand for the product of the outside country. If the affected trade flow is large enough to matter at all, then this will cause a fall in the world price of the imported good and a worsening of the terms of trade of the outside country.

This does not have to happen. PTAs can take several forms, in particular with regard to the tariffs that the countries levy on trade from outside. If these tariffs are low enough, then the countries of the PTA may continue to trade with the rest of world as much as they did before. Kemp and Wan (1976), for example, showed that a customs union could set a common external tariff that would keep net imports of every good from the rest of the world unchanged, thus assuring no impact at all on the well being of the rest of the world. ${ }^{8}$ However, if external tariffs are not changed when the PTA is formed, as is usually the case in a free trade area (FTA), then the fact that the preferences favor

\footnotetext{
${ }^{8}$ Panagariya and Krishna (2000) showed a similar result for free trade areas.
} 
trade with partners over trade with outside countries suggests that trade with the rest of world is likely to fall.

If that happens, then the effect on the excluded countries is exactly like Figure 1 in reverse. That is, the collective offer curve of the countries of the FTA before it is formed is $\mathrm{OA}^{\prime}$, and formation of the FTA shifts it inward to OA, causing a worsening of the excluded country's terms of trade.

Even with an FTA and unchanged external tariffs, this is not a necessary outcome, although it seems far more likely than the alternative. For example, in a two-country model, suppose that the FTA includes countries A and B which import goods X and Y respectively over positive tariffs. When they eliminate these tariffs on trade with each other, at the initial world price each will import from the other instead of from the outside world, as long as each can supply all of the other's needs at a price differing from the world price by less than the tariff. If this is the case, then whatever may have been the two-countries' combined trade with the world before the FTA, this trade shrinks to zero in its presence. Only if the countries differ in size by enough that one of them cannot meet the other's demands at such a price will the two together continue to trade with the world at the initial price. And even then it is likely that their combined net trade will shrink. ${ }^{9,10}$

Thus, while exceptions do seem to be possible, on the whole it seems that preferential liberalization is even more likely to be harmful than multilateral

\footnotetext{
${ }^{9}$ However, this does not seem to be inevitable. In analysis not included here, it appears to be possible to construct a case where opposite income effects in the two FTA countries cause an increase in their net trade with the world.

${ }^{10}$ Another case would have both of the FTA members importing the same good from the world. If their tariffs are the same, then the FTA has no effect on this trade. But if their tariffs are different, then as pointed out by Richardson (1995), the high-tariff country will import as much as possible from the lowtariff country, which will expand its imports to replace those of the high-tariff country. In this case, too, net trade of the two may expand since, in effect, the tariff of the high-tariff country is rendered irrelevant.
} 
liberalization to those countries that do not participate in it. Note that this does not require that trade diversion somehow outweigh trade diversion, but just that it occur at all. The same conclusion can also be obtained by different means in different models. Chang and Winters (2002), for example, argue (and support empirically, with data from MERCOSUR) that preferential liberalization favoring one of two Bertrand competitors will cause the unfavored firm to lower its export price. No doubt there are many other mechanisms that could work as well.

\section{Conclusion}

This analysis suggests that, although it is not inevitable, it is strongly likely that excluded countries will be hurt by trade liberalization by other countries. It may be true that, if tariff reductions are MFN on products that are selected at random, then an excluded country has as good a chance of gaining from them as of losing. But MFN tariff reductions have not in practice been in randomly selected sectors, but rather in sectors in which the tariff-reducing countries stand most to gain as exporters. Thus tariffs are unlikely to be cut on products that are primarily exported by the excluded countries. Furthermore, much of the trade liberalization that has occurred in recent years has been preferential, not MFN. While preferential liberalization usually covers (almost) all products, its discriminatory nature means that it tends to divert trade away from excluded countries and thereby makes them worse off.

It is also true that these losses from trade liberalization occur only because the excluded countries do in fact trade. The effects discussed here all work through the terms of trade, and a country would be immune from them if it did not trade at all. But this is 
no reason not to trade, for these losses all represent a reduction of their gains from trade, not a reduction of welfare to below what it would have been in autarky. Thus the excluded countries would be ill-advised to exclude themselves even further from world markets as a means of avoiding these losses. It won't work.

Nor is it a reason for trade liberalization itself to be restrained, at least not in its MFN manifestation. As should be clear from this analysis, the reason that excluded countries may lose from trade liberalization is that the liberalization does not go far enough, not that it goes too far. It is the exclusion of some sectors and/or some exporting countries from the benefits of tariff cuts that creates a bias against excluded countries.

Thus the best chance of avoiding these losses to excluded countries is simply not to exclude them. Or, if they cannot be persuaded to participate, we need to find a mechanism for cutting tariffs that will work across all sectors instead of favoring only the export sectors of the participating countries.

The current multilateral trade negotiations of the Doha Development Agenda show promising signs of doing exactly this. Developing countries are playing a more active role than ever before, at least in pressing the developed countries to reduce trade barriers in sectors of export interest to them. At the same time, developed countries are insisting that the developing countries also participate more than they have before by reducing their own tariffs. If both of these outcomes can be achieved, developing countries - at least those who participate - will stand to gain substantially. Even those countries that remain outside the WTO may gain from this, to the extent that tariffs are reduced on their exports as well. 
Preferential liberalization, in the form of proliferating FTAs, poses a more difficult problem. If this proliferation does not abate, there are only two ways that an excluded country may hope to avoid being harmed by it. One is to join in and negotiate FTAs of its own with as many partners as it can. Unfortunately, the poorer a country is, the less likely it is that others will have any interest in negotiating with it. And even if FTAs were to be formed including all possible pairings or groupings of countries, the administrative complications of conforming to all of their rules would put the poorest countries as a disadvantage.

The other route toward lessening the harm from preferential liberalization, as it affects excluded countries, is for nondiscriminatory liberalization to render preferences meaningless. If MFN tariffs were all zero, then any FTA would be both unnecessary and ineffective. Thus the best cure for the side effects of preferential trade liberalization is nondiscriminatory trade liberalization. 


\section{References}

Chang, Won and L. Alan Winters 2002 "How Regional Blocs Affect Excluded Countries: The Price Effects of MERCOSUR," American Economic Review 92(4), September, pp. 889904.

Findlay, R. and S. Wellisz 1982 "Endogenous Tariffs, the Political Economy of Trade Restrictions, and Welfare," in Jagdish Bhagwati, ed., Import Competition and Response, Chicago: University of Chicago Press.

Grossman, Gene M. and Elhanan Helpman 1994 "Protection for Sale," American Economic Review 84, September, pp. 833-850.

Hillman, Arye L. 1989 The Political Economy of Protection, London: Harwood.

Kemp, Murray C. and Henry Y. Wan, Jr. 1976 "An Elementary Proposition Concerning the Formation of Customs Unions," in Murray Kemp, Three Topics in the Theory of International Trade: Distribution, Welfare, and Uncertainty, Amsterdam: North Holland.

Mayer, Wolfgang 1984 "Endogenous Tariff Formation," American Economic Review 74, pp. 970985.

Meade, James Edward 1952 A Geometry of International Trade, London: Unwin Brothers Ltd.

Panagariya, Arvind and Pravin Krishna 2000 "On Necessarily Welfare-Enhancing Free Trade Areas," Journal of International Economics 57, pp. 353-367.

Richardson, Martin 1995 "Tariff Revenue Competition in a Free Trade Area," European Economic Review 39, pp. 1429-37.

Viner, Jacob 1950 The Customs Union Issue, New York: Carnegie Endowment for International Peace. 


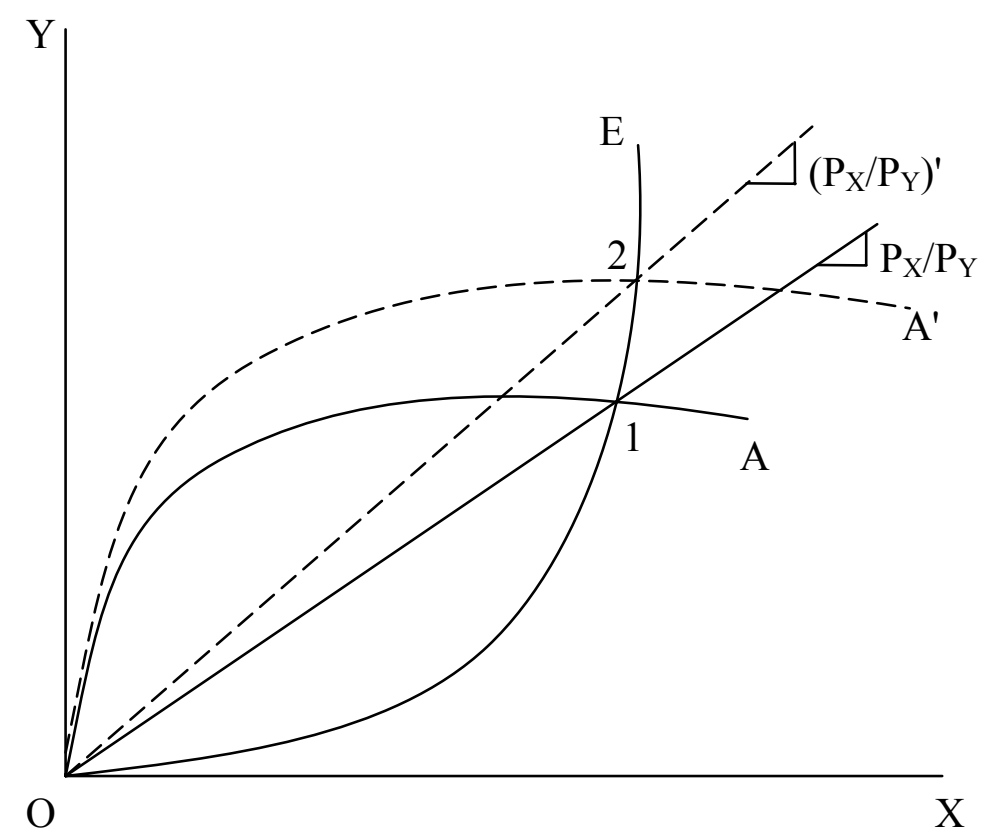

Figure 1

The Excluded Country, E, gains when the rest of world, A, liberalizes. 


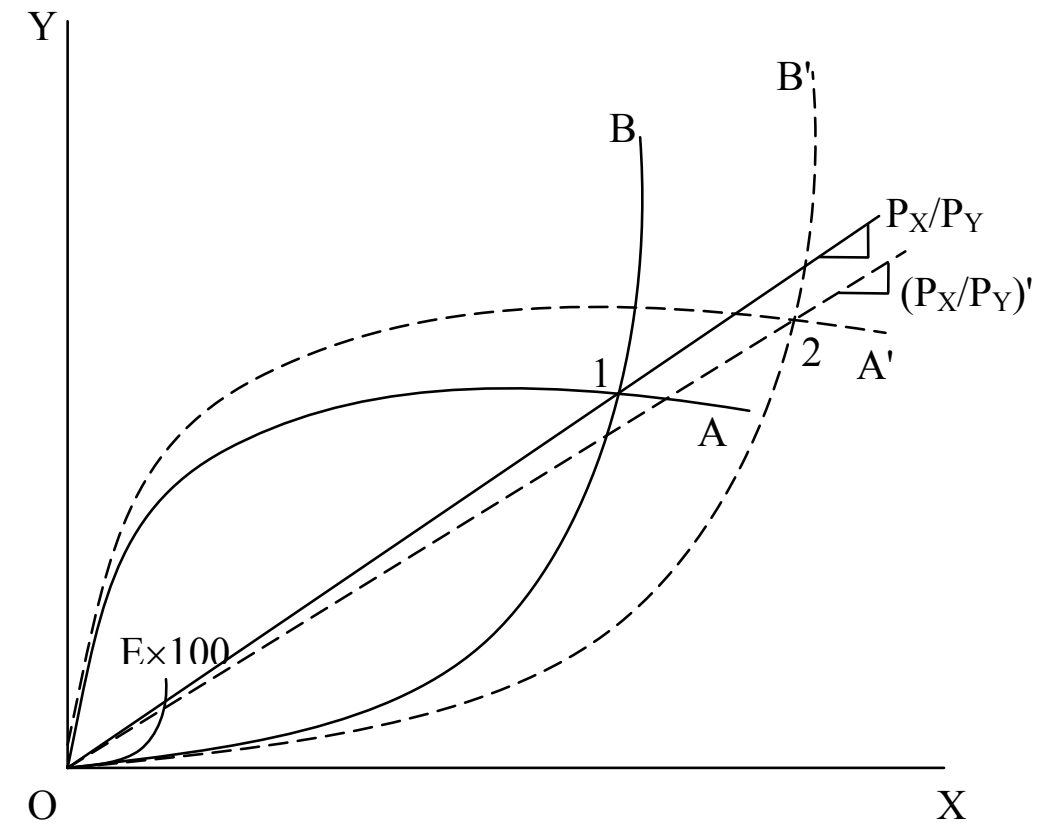

Figure 2

The Excluded Country, E, loses when other exporters of X (Country B) liberalize more than other importers of X (Country A). 